\title{
Chrysophycean stomatocysts from the Staw Toporowy Nizni lake (Tatra National Park, Poland)
}

\author{
J. Cabala ${ }^{1}$, M. Piatek ${ }^{2}$
}

\footnotetext{
${ }^{1}$ Department of Phycology, W. Szafer Institute of Botany, Polish Academy of Sciences, Lubicz 46, PL-31-512 Kraków, Poland. E-mail: cabala@ib-pan.krakow.pl

2 Department of Mycology, W. Szafer Institute of Botany, Polish Academy of Sciences, Lubicz 46, PL-31-512 Kraków, Poland.

E-mail: mpiatek@ib-pan.krakow.pl
}

Thirty-six chrysophycean stomatocysts are reported from the dystrophic Staw Toporowy Nizni lake in the Tatra National Park, Poland. Of these, 7 morphotypes are new to science, 10 are new to Europe, and 13 are new to Poland. SEM micrographs and data on distribution are provided for each stomatocyst. Synonimizations of two stomatocysts are proposed: stomatocyst 58 Hansen 2001 with stomatocyst 117 Zeeb et al. 1990, and stomatocyst 91 Hansen 2001 with stomatocyst 239 Duff et al. 1995. The number of chrysophycean stomatocysts recorded from Poland is currently estimated to comprise 65 extant morphotypes.

Keywords : Stomatocysts, Chrysophyceae, new morphotypes, taxonomy, Staw Toporowy Nizni lake, Tatra National Park, Poland.

\section{Introduction}

In Poland, stomatocysts have been only studied in upland habitats (Cabala 2002, 2003a, b). Investigations in mountainous areas of the Tatra National Park began in 2003, and we present here the first study of chrysophycean stomatocysts. Similar investigations have been carried out in other European mountains, including the Bohemian Forest, the Vosges, the Bavarian Forest, the Alps (Facher \& Schmidt 1996, Kamenik et al. 2001), and the Pyrenees (Pla 2001). The aims of our work were: (i) to describe and document the stomatocysts observed in the Staw Toporowy Nizni lake, according to the International Statospore Working Group guidelines (ISWG, Cronberg \& Sandgren 1986); (ii) to describe the chemical and physical parameters of the water in which the stomatocysts were found; and (iii) to examine correlations between morphological characteristics and the occurrence of stomatocysts in various parts of the peat bog.

\section{Study area}

The Tatra National Park is located in the Carpathian Mountains of South-Poland (Fig. 1A). It includes the entire territory of the Polish Tatra Mountains, and a small part of the adjacent area. It is a high mountain national park, ranging from 900 to $2500 \mathrm{~m}$ a.s.l., and including vegetation belts from the lower mountain to

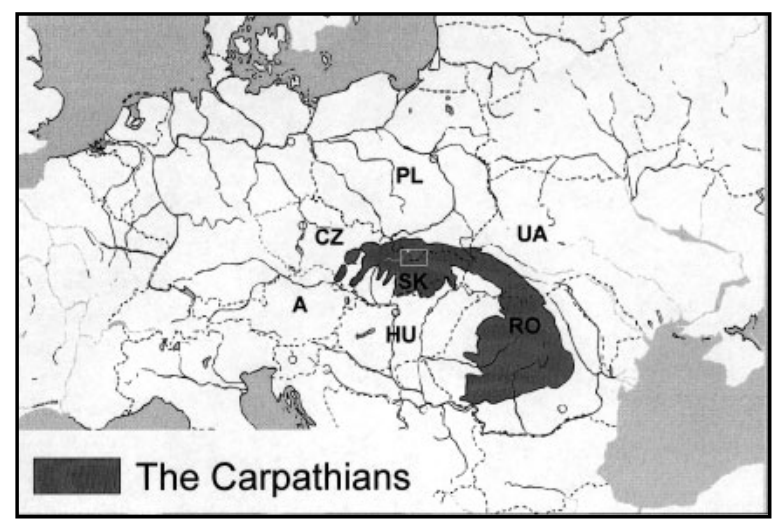

Fig. 1. A) Location of the study area in the Carpathians; 
the alpine zones. The Staw Toporowy Nizni lake (1089 $\mathrm{m}$ a.s.l.) is the lowest lake in the Tatra National Park (Fig. 1B). It covers an area of 0.617 ha and is $5.7 \mathrm{~m}$ deep, $185.5 \mathrm{~m}$ in length and $51.3 \mathrm{~m}$ in width (Mirek \& Piekos-Mirkowa 1995, Lajczak 1996). This lake is surrounded by spruce forest of the lower montane belt.

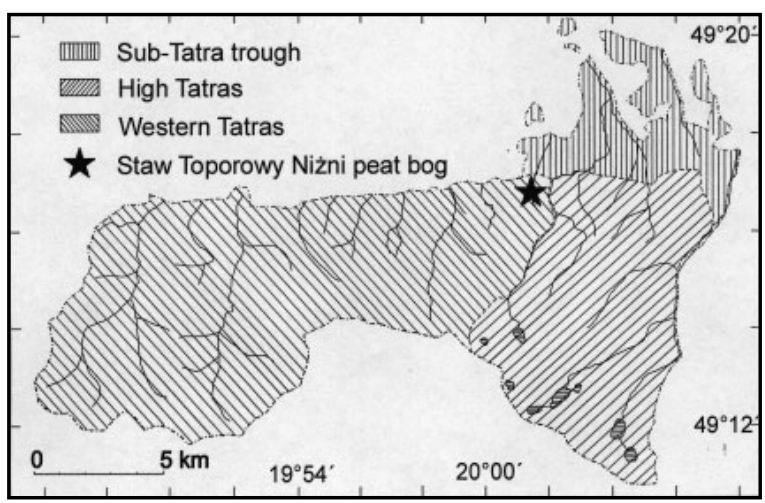

Fig. 1. B) Location of the Staw Toporowy Nizni peat bog in the Tatra National Park.

The margins of the lake are covered by vascular plants which are typical for water, marshy, and peat bog habitats. Several plants are common in lowlands, but rarely occur in the Tatra National Park, namely Callitriche cophocarpa Sendtn., C. hamulata Kütz. ex W.D.J. Koch, Carex vesicaria L., Potamogeton natans L. and Stellaria longifolia Muhl. ex Willd. (Mirek \& PiekosMirkowa 1995). The algal flora of the Staw Toporowy Nizni was briefly characterized by Szklarczyk-Gazdo-

Table 1. Chemical and physical parameters of the Toporowy Staw Nizni peat bog in Tatra National Park.

\begin{tabular}{ll}
\hline Chemical and physical parameters & Measurements \\
\hline Ammonium $\left(\mathrm{NH}^{+}\right)$ & $0.0 \mathrm{mg} / \mathrm{l}$ \\
Nitrite $\left(\mathrm{NO}{ }^{-}\right)$ & $0.0-0.025 \mathrm{mg} / \mathrm{l}$ \\
Nitrate $\left(\mathrm{NO}^{-}\right)$ & $0.0 \mathrm{mg} / \mathrm{l}$ \\
$\mathrm{pH}$ & 5.0 \\
Total hardness & $0.0 \mathrm{mmol} / \mathrm{l}=0^{\circ} \mathrm{d}$ \\
Carbonate hardness & \\
(acid-binding capacity) & $0.0 \mathrm{mmol} / \mathrm{l}=0^{\circ} \mathrm{d}$ \\
Residual hardness & $0.0 \mathrm{mmol} / \mathrm{l}=0^{\circ} \mathrm{d}$ \\
Oxygen $\left(\mathrm{O}_{2}\right)$ & $10 \mathrm{mg} / 1$ \\
Temperature of water & $10^{\circ} \mathrm{C}$ \\
Phosphate $\left(\mathrm{PO}_{4}{ }^{3-}\right)$ & $0.0-0.25 \mathrm{mg} / 1$ \\
Conductivity & $42 \mu \mathrm{S}$
\end{tabular}

wa (1960). The most common algae were Netrium digitus (Ehr.) Itzigs. \& Rothe, Closterium setaceum Ehr. ex Ralfs, Pleurothaenium trabecula Ehr. ex Näg., Micrasterias rotata (Grev.) Ralfs ex Ralfs, Staurastrum spp. and Cosmarium spp. During our study, we observed representatives of Bacillariophyceae, Zygnematophyceae, Euglenophyceae and Cyanophyceae. At the north end of the lake, there is a small peat bog with tufts of Sphagnum spp. and Carex spp. The material for the chrysophycean stomatocyst studies was collected from this peat bog. Its chemical and physical parameters are summarized in Table 1.

\section{Material and methods}

The material was collected on the $29^{\text {th }}$ of April 2003. Collections included: (i) surface water, (ii) water from beneath the surface, $40-60 \mathrm{~cm}$ deep, (iii) sediment from the bottom of the peat bog at a depth of $0-10 \mathrm{~cm}$, and (iv) water squeezed from Sphagnum spp. into 120 $\mathrm{ml}$ plastic containers. The samples were preserved with $4 \%$ formaldehyde. Each sample was placed in a glass scintillation vial, covered with $10 \% \mathrm{HCl}$ (to remove carbonates) and allowed to stand for 24 hours, boiled for 15 minutes, then rinsed several times with distilled water. The samples were covered with $30 \%$ $\mathrm{H}_{2} \mathrm{O}_{2}$ and allowed to stand for 24 hours, then boiled for 30 minutes with a pinch of $\mathrm{ClO}_{3}$ added at ca. 15-minute intervals, then rinsed several times with distilled water, with a settling time of 24 hours between each aspiration. Finally the samples were slurried in glass vials and covered with $95 \%$ alcohol.

For light microscope (LM) analysis, a small aliquot of slurry was pipetted onto glass cover slips and allowed to evaporate before being mounted with Naphrax ${ }^{\circledR}$ on glass slides. Specimens were examined with an Amplival Carl Zeiss Jena microscope equipped with an Apochromat 100x oil immersion objective, without phase contrast.

For scanning electron microscope (SEM) analysis, another aliquot of each slurry was pipetted onto clean glass, air-dried, and affixed to an aluminium stub with double-sided transparent tape. The stubs were sputtercoated with gold using a CRESSINGTON and viewed with a Hitachi S-4700, with a working distance of ca 12-13 mm. Cysts were measured and described from scanning electron micrographs according to International Statospore Working Group (ISWG) guidelines (Cronberg \& Sandgren 1986), and according to the taxonomy of Duff et al. (1995), Facher and Schmidt (1996), Vorobyova et al. (1996), van de Vijver \& Beyens (1997a,b, 2000), Hansen (2001), Kamenik et 
al. (2001), Pla (2001) and Wilkinson et al. (2001). New stomatocysts not previously published were assigned numbers from Cabala (Wolowski et al., in press), beginning with stomatocyst \#12. Cabala J. and Piatek are cited as «this paper». «Number of specimens» refers to the number of scanning electron micrographs used for the description of the stomatocysts. Negatives are deposited in the Iconotheca of Algae (KRAM) in the Department of Phycology of the W. Szafer Institute of Botany, Polish Academy of Sciences, Krakow.

\section{Results}

Chrysophycean stomatocysts are formed in response to endogenous and exogenous cues, ensuring that seed chrysophyte populations exist at all times (Wilkinson \& Smol 1998). This fact nicely corresponds with our observations from the peat bog. Although the material was collected almost immediately after the snow melted, the stomatocyst diversity was high. No free swimming forms of chrysophytes were observed at that time. A total of 36 stomatocyst morphotypes were thus recorded. Among them, 7 morphotypes were new to science, 10 morphotypes were new to Europe and 13 morphotypes were new to Poland. Together with previous papers (Cabala 2002, 2003a, b, Wolowski et al., in press), 65 extant morphotypes of chrysophycean stomatocysts were recorded in Polish water bodies. The number of known stomatocysts in Poland will certainly increase as the study of stomatocysts in Polish water reservoirs and peat bogs progresses, since studies of these forms have only begun recently. The high percentage of new morphotypes $(19.4 \%)$ observed in this study is not surprising, as this is the first SEM study of chrysophyte stomatocysts in the Tatra National Park. Unfortunately, the biological affinities of all the new cysts are unknown.

All stomatocysts were viewed with scanning electron microscopy (SEM), and some with light microscopy (LM). Most of these stomatocysts showed low abundance. Only stomatocysts 351 Zeeb \& Smol, 204, 73, 86 Duff \& Smol and 16, 18 Cabala J. occurred frequently. This result may be an artefact for several reasons; for example, some of the cysts were difficult to distinguish under LM and even SEM, since several morphotypes are amalgamated and very similar morphologically.

The recorded cysts were grouped by common morphological characteristics following Duff et al. (1995), Pla (2001) and Wilkinson et al. (2001) (Table 2). Asterisks indicate morphotypes new to Poland $(*)$, new to Europe $(* *)$, and described here for the first time $(* * *)$.
Unornamented stomatocysts (Duff et al. 1995, Wilkinson et al. 2001)

Lacking collar

Stomatocyst 9, Duff \& Smol 1988 emend. Zeeb \& Smol 1993 (Fig. 2). Negative number: 2N-09. Number of specimens: 3 . Biological affinity: This cyst is probably produced by several species, including Chrysolepidomonas dendrolepidota Peters \& Andersen 1993. Locality: Staw Toporowy Nizni peat bog (49 $17^{\prime} \mathrm{N}$, $20^{\circ} 02^{\prime} \mathrm{E}$ ), water from beneath the surface. SEM description: This is smooth and spherical stomatocyst, 8.0-8.6 $\mu \mathrm{m}$ in diameter. The pore is regular, $0.5-0.6 \mu \mathrm{m}$ in diameter, the collar is absent. This stomatocyst is distinguished from stomatocysts 1 and 15 Duff \& Smol on the basis of size; from stomatocysts 120 Duff \& Smol and 189 Zeeb \& Smol on the basis of pore morphology (Duff et al. 1995). References: This stomatocyst has been found in Canada, U.S.A., Greenland (Duff et al. 1995), central Europe (Facher \& Schmidt 1996), the Spanish part of Pyrenees (Pla 2001) and in Poland in the Staszów sink-hole (Wolowski et al., in press).

Stomatocyst 120, Duff \& Smol in Duff et al. 1992 emend. Zeeb \& Smol 1993 (Fig. 3). Negative number: 2N-03. Number of specimens: 4. Biological affinity: This stomatocyst may be produced by more than one species, e.g. Chrysosphaerella longispina Lauteborn emend. K. H. Nicholls (Duff et al.1995). Locality: Staw Toporowy Nizni peat bog (49 $17^{\prime}$ N , $\left.20^{\circ} 02^{\prime} \mathrm{E}\right)$, water from beneath the surface and sediment from the bottom of the peat bog. SEM description: This is smooth and spherical stomatocyst, 7.6-8.3 $\mu \mathrm{m}$ in diameter. The pore is regular and concave, inner pore 0.4$0.5 \mu \mathrm{m}$ in diameter, the collar is absent. This stomatocyst is distinguished from stomatocysts 29 and 42 Duff \& Smol on the basis of size; from stomatocysts 9 Duff \& Smol, 189 Zeeb \& Smol and 22 Hansen on the basis of pore size and/or morphology (Duff et al. 1995, Hansen 2001). References: This stomatocyst has been found in Canada, U.S.A., Greenland (Duff et al. 1995), central Europe (Facher \& Schmidt 1996), the Spanish part of Pyrenees (Pla 2001) and in Poland (Cabala 2002, Wolowski et al., in press).

With a simple conical collar

**Stomatocyst 308, Brown \& Smol in Brown et al. 1997. (Fig. 4). Negative number: 3N-24. Number of specimens: 1. Biological affinity: Unknown. Locality: Staw Toporowy Nizni peat bog $\left(49^{\circ} 17^{\prime} \mathrm{N}, 2^{\circ} 02^{\prime} \mathrm{E}\right)$, sediment from the bottom of the peat bog. SEM description: This stomatocyst is smooth to slightly scabrate (scabrae with $0.2 \mu \mathrm{m}$ in diameter) and spherical, 6.5 $\mu \mathrm{m}$ in diameter. The pore is deep and concave. The 
Table 2. A listing of the identified stomatocysts observed in the Staw Toporowy Nizni peat bog, along with their primary reference(s) and their occurrence in various parts of peat bog. Stomatocysts are listed in order according to their common morphological characteristics as described by Duff et al. (1995), Pla (2001) and Wilkinson et al. (2001).

\begin{tabular}{|c|c|c|c|c|}
\hline Stomatocysts \# and primary reference(s) & $\begin{array}{c}\text { surface } \\
\text { water }\end{array}$ & $\begin{array}{c}\text { water } \\
\text { from } \\
\text { beneath } \\
\text { the } \\
\text { surface, } \\
40-60 \mathrm{~cm} \\
\text { deep }\end{array}$ & $\begin{array}{l}\text { sediment } \\
\text { from the } \\
\text { bottom, } \\
0-10 \mathrm{~cm} \\
\text { deep }\end{array}$ & $\begin{array}{c}\text { water } \\
\text { squeezed } \\
\text { from } \\
\text { Sphagnum } \\
\text { spp. }\end{array}$ \\
\hline
\end{tabular}

Unornamented stomatocysts

Lacking collar

9 Duff \& Smol 1988 emend. Zeeb \& Smol 1993

120 Duff \& Smol in Duff et al. 1992 emend

Zeeb \& Smol 1993

With a simple conical collar

308 Brown \& Smol in Brown et al. 1997

181 Brown \& Smol in Brown et al. 1994

33 van de Vijver \& Beyens $1997 \mathrm{~b}$

351 Zeeb \& Smol in Szeicz et al. 1998

With a simple cylindrical collar

52 Duff \& Smol 1991 emend. Duff et al. 1995

146 Zeeb \& Smol in Pienitz et al. 1992

125 Duff \& Smol in Duff et al. 1992

183 Brown \& Smol in Brown et al. 1994

56 Duff \& Smol 1991

118 Zeeb et al. 1990

11 Facher E. \& Schmidt R. 1996

\#12 Cabała J., this paper

With a simple obconical collar

182 Brown \& Smol in Brown et al. 1994

With a true or false complex collar

273 Gilbert \& Smol in Gilbert et al. 1997

135 Duff \& Smol 1991 (in Pla 2001)

16 Duff \& Smol in Duff et al. 1995

204 Duff \& Smol 1994

Ornamented stomatocysts

With anterior projections simulating

simple/complex collar

\#13 Cabała J., this paper

With scabrae

117 Zeeb et al 1990

178 Zeeb \& Smol 1993

188 Brown \& Smol in Brown et al. 1994

$\$ 14$ Cabała J., this paper

With verrucae

\#15 Cabała J., this paper

With conula

283 Gilbert \& Smol in Gilbert et al. 1997

With spines

73 Duff \& Smol 1991

83 Duff \& Smol 1991

67 van de Vijver B. \& Beyens L. 2000

With ridges

11 Duff \& Smol 1988 emend. Gilbert \& Smol in

Gilbert et al. 1997

239 Duff et al. 1995

91 Duff \& Smol 1991

\#16 Cabała J., this paper

With a reticulum

\#17 Cabała J., this paper

\#18 Cabała J., this paper

With compound ornamentation

86 Duff \& Smol 1991 

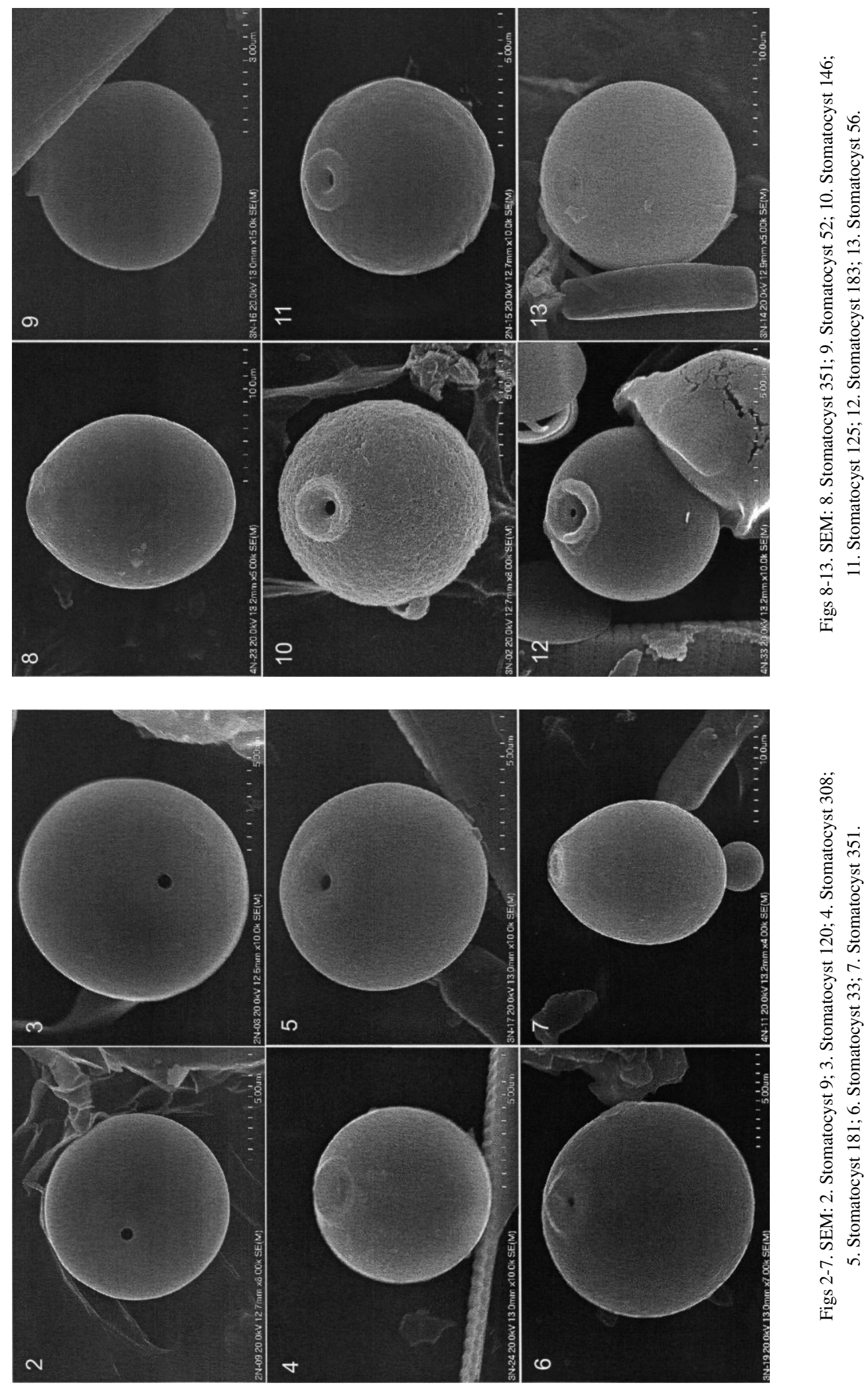

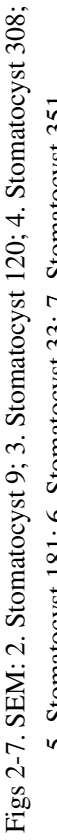


collar is slightly conical, $2.3 \mu \mathrm{m}$ in diameter. This stomatocyst is distinguished from stomatocysts 46 Duff $\&$ Smol and 189, 150 Zeeb \& Smol on the basis of pore morphology; from stomatocysts $393 \mathrm{Pla}$ and $23 \mathrm{Fa}$ cher \& Schmidt on the basis of surface with scabrae. References: This stomatocyst has been found in Canada and Russia - Siberia (Wilkinson et al. 2001).

Stomatocyst 181, Brown \& Smol in Brown et al. 1994. (Fig. 5). Negative number: 3N-17. Number of specimens: 1. Biological affinity: Unknown. Locality: Staw Toporowy Nizni peat bog $\left(49^{\circ} 17^{\prime} \mathrm{N}, 20^{\circ} 02^{\prime} \mathrm{E}\right)$, sediment from the bottom of the peat bog. SEM description: This stomatocyst is smooth and spherical, 7.7 $\mu \mathrm{m}$ in diameter. The collar is slightly conical, $2.7 \mu \mathrm{m}$ in diameter, $0.6 \mu \mathrm{m}$ in height, and wide, rounded apex. The pore is regular, $0.5 \mu \mathrm{m}$ in diameter. This stomatocyst is distinguished from stomatocysts 146 and 156 Zeeb \& Smol on the basis of collar morphology. References: This stomatocyst has been found in Canada, U.S.A., Greenland (Duff et al. 1995) and Poland (Cabala 2002).

**Stomatocyst 33, van de Vijver \& Beyens 1997b (Fig. 6). Negative number: 3N-19. Number of specimens: 1. Biological affinity: Unknown. Locality: Staw Toporowy Nizni peat bog $\left(49^{\circ} 17^{\prime} \mathrm{N}, 20^{\circ} 02^{\prime} \mathrm{E}\right)$, sediment from the bottom of the peat bog. SEM description: This stomatocyst is smooth and spherical, 11.7 $\mu \mathrm{m}$ in diameter. The collar is conical, 3.0 ( $\mathrm{m}$ in diameter and $0.6 \mu \mathrm{m}$ in height. The pore is concave, $0.5(\mathrm{~m}$ in diameter. This stomatocyst is distinguished from stomatocysts 123 Duff \& Smol and 23 Facher \& Schmidt on the basis of size of body and collar; from 181 Brown \& Smol on the basis of size of cyst body and pore morphology. References: This stomatocyst has been found in South Georgia (van de Vijver \& Beyens 1997b).

**Stomatocyst 351, Zeeb \& Smol in Szeicz et al. 1998 (Figs 7-8, 48-49). Negative number: 4N-11. Number of specimens: 10. Biological affinity: This stomatocyst is possibly related to Mallomonas hamata Asmund and/or M. heterospina Lund. (Wilkinson et al. 2001). Locality: Staw Toporowy Nizni peat bog (49 $17^{\prime}$ N, $20^{\circ} 02^{\prime}$ E), water squeezed from Sphagnum spp. SEM description: This stomatocyst is large and ovate, $14.0-15.8 \mu \mathrm{m}$ long, $12.9-14.0 \mu \mathrm{m}$ wide. The collar is conical, $6.0-7.2 \mu \mathrm{m}$ in diameter and $1.1 \mu \mathrm{m}$ in height. The pore and accretions were obscured by a flattened, convex siliceous cap, $4.0 \mu \mathrm{m}$ in diameter and $1.4 \mu \mathrm{m}$ in height. The cyst surface is smooth. This sto- matocyst is distinguished from stomatocyst 202 Duff $\&$ Smol on the basis of collar and cap morphology (Wilkinson et al. 2001). References: This stomatocyst has been found in Chile, but it is not definitely identified elsewhere (Wilkinson et al. 2001).

\section{With a simple cylindrical collar}

*Stomatocyst 52, Duff \& Smol 1991 emend. Duff et al. 1995 (Fig. 9). Negative number: 3N-16. Number of specimens: 1. Biological affinity: This stomatocyst is produced by more than one species (Duff et al. 1995). Locality: Staw Toporowy Nizni peat bog $\left(49^{\circ} 17^{\prime} \mathrm{N}\right.$, $\left.20^{\circ} 02^{\prime} \mathrm{E}\right)$, sediment from the bottom of the peat bog. SEM description: This stomatocysts is small, smooth and spherical, $4.8 \mu \mathrm{m}$ in diameter. The collar is cylindrical, $1.2 \mu \mathrm{m}$ in diameter and $0.3 \mu \mathrm{m}$ in height. This stomatocyst is distinguished from stomatocysts 110 Zeeb et al. and 50 Duff \& Smol on the basis of collar size. References: This stomatocyst has been found in U.S.A., Greenland (Duff et al. 1995), central Europe (Facher \& Schmidt 1996) and the Spanish part of Pyrenees (Pla 2001).

**Stomatocyst 146, Zeeb \& Smol in Pienitz et al. 1992. (Fig. 10). Negative number: 3N-02. Number of specimens: 1. Biological affinity: Unknown. Locality: Staw Toporowy Nizni peat bog $\left(49^{\circ} 17^{\prime} \mathrm{N}, 2^{\circ} 02^{\prime} \mathrm{E}\right)$, sediment from the bottom of the peat bog. SEM description: This stomatocyst ranges from smooth to psilate and spherical, $9.6 \mu \mathrm{m}$ in diameter. The collar is short and cylindrical, $2.6 \mu \mathrm{m}$ in diameter, $0.5 \mu \mathrm{m}$ in height and a sloping planar annulus. The pore is regular to slightly conical, $0.7 \mu \mathrm{m}$ in diameter. This stomatocyst is distinguished from stomatocyst 234 Duff et al. on the basis of size, ornamentation and size of collar. Notes: The diameter of our stomatocyst is larger than in original description $(6.6-8.6 \mu \mathrm{m})$. References: This stomatocyst has been found in Canada and U.S.A. (Duff et al. 1995).

*Stomatocyst 125, Duff \& Smol in Duff et al. 1992. (Fig. 11). Negative number: $2 \mathrm{~N}-15$. Number of specimens: 2. Biological affinity: This stomatocyst is produced by Paraphysomonas antarctica Takahashi (Takahashi 1987). Locality: Staw Toporowy Nizni peat bog $\left(49^{\circ} 17^{\prime} \mathrm{N}, 20^{\circ} 02^{\prime} \mathrm{E}\right)$, water from beneath the surface. SEM description: This stomatocyst is smooth and spherical, 7.4-7.9 $\mu \mathrm{m}$ in diameter. The collar is low and cylindrical, 1.8-2.1 $\mu \mathrm{m}$ in diameter and 0.3-0.4 $\mu \mathrm{m}$ in height, with a thickened and flattened apex. The pore is regular, $0.4-0.5 \mu \mathrm{m}$ in diameter. This stomatocyst 
is distinguished from stomatocysts 181 and 182 Brown $\&$ Smol on the basis of pore and collar morphology; from stomatocyst 358 Taylor \& Smol on the basis of size of cyst body and collar. Notes: The diameter of our stomatocyst is slightly larger than in original description $(6.0-7.2 \mu \mathrm{m})$, the collar has also larger dimensions (1.3-1.8 $\mu \mathrm{m})$. References: This stomatocyst has been found in Canada (Duff et al. 1995) and the Spanish part of Pyrenees (Pla 2001).

* Stomatocyst 183, Brown \& Smol in Brown et al. 1994 (Fig. 12). Negative number: 4N-33. Number of specimens: 3. Biological affinity: Unknown. Locality: Staw Toporowy Nizni peat bog $\left(49^{\circ} 17^{\prime} \mathrm{N}, 20^{\circ} 02^{\prime} \mathrm{E}\right)$, water squeezed from Sphagnum spp. SEM description: This stomatocyst is smooth and spherical, 6.4-7.2 $\mu \mathrm{m}$ in diameter. The collar is cylindrical, $2.2-2.8 \mu \mathrm{m}$ in diameter and $0.4-0.5 \mu \mathrm{m}$ in height, with an irregular and thickened apex. The regular pore, 0.3-0.4 $\mu \mathrm{m}$ in diameter, is surrounded by shallow, wide, flat planar to swollen annulus. References: This stomatocyst has been found in U.S.A., Greenland (Duff et al. 1995), Azores (Hansen 2001) and the Spanish part of Pyrenees (Pla 2001).

Stomatocyst 56, Duff \& Smol 1991 (Fig. 13). Negative number: $3 \mathrm{~N}-14$. Number of specimens: 1. Biological affinity: Unknown. Locality: Staw Toporowy Nizni peat bog $\left(49^{\circ} 17^{\prime} \mathrm{N}, 20^{\circ} 02^{\prime} \mathrm{E}\right)$, sediment from the bottom of the peat bog. SEM description: This stomatocyst is smooth to psilate, spherical, $14.5 \mu \mathrm{m}$ in diameter. The collar is low and cylindrical, $3.3 \mu \mathrm{m}$ in diameter and $0.3 \mu \mathrm{m}$ in height, with an acute apex and a sloping planar annulus. The pore is obscured on SEM, convex siliceous plug. This stomatocyst is distinguished from stomatocyst 112 Zeeb et al. on the basis of size of collar; from stomatocyst 241 Duff et al. on the basis of size and ornamentation. Notes: The diameter of our stomatocyst is larger than in original description (10.1-13.1 $\mu \mathrm{m})$. References: This stomatocyst has been found in U.S.A., Poland (Duff et al. 1995) and the Spanish part of Pyrenees (Pla 2001).

*Stomatocyst 118, Zeeb et al. 1990. (Figs 14-15). Negative number: 4N-35. Number of specimens: 2 . Biological affinity: This stomatocyst is produced by Mallomonas akrokosmos Ruttner in Pascher (Cronberg 1980). Locality: Staw Toporowy Nizni peat bog $\left(49^{\circ} 17^{\prime} \mathrm{N}, 20^{\circ} 02^{\prime} \mathrm{E}\right)$, water from beneath the surface and water squeezed from Sphagnum spp. SEM description: This stomatocyst has smooth and oval surfa- ce, 9.3-11.4 $\mu \mathrm{m}$ long, 6.4-8.2 $\mu \mathrm{m}$ wide. The collar is cylindrical with fluted outer margin, 2.9-3.2 $\mu \mathrm{m}$ in diameter and 0.6-0.7 $(\mathrm{m}$ in height. The pore is regular, 0.5 $\mu \mathrm{m}$ in diameter. Notes: The length and width of our stomatocyst are larger than in original description (6.1$7.6 \times 7.8-10.2 \mu \mathrm{m})$. References: This stomatocyst has been found in Canada, U.S.A., Austria, Germany, Italy, Romania, Argentina (Duff et al. 1995), central Europe (Facher \& Schmidt 1996) and the Spanish part of Pyrenees (Pla 2001).

*Stomatocyst 11, Facher E. \& Schmidt R. 1996 (Fig. 16). Negative number: $3 \mathrm{~N}-08$. Number of specimens: 1. Biological affinity: Unknown. Locality: Staw Toporowy Nizni peat bog $\left(49^{\circ} 17^{\prime} \mathrm{N}, 20^{\circ} 02^{\prime} \mathrm{E}\right)$, sediment from the bottom of the peat bog. SEM description: This stomatocyst is smooth-surface and spherical, 11.3 $\mu \mathrm{m}$ in diameter. The collar is cylindrical, $1.3 \mu \mathrm{m}$ in diameter and $0.8 \mu \mathrm{m}$ in height. The pore is regular. This stomatocyst is distinguished from stomatocyst 327 Wilkinson \& Smol on the basis of size and collar morphology. References: This stomatocyst has been found in central Europe (Facher \& Schmidt 1996).

***Stomatocyst \#12, Cabala J., this paper (Figs 17 \& 50) Negative number: J. Cabala, negative 2N-20, Fig. 17. Number of specimens: 2. Biological affinity: Unknown. Locality: Staw Toporowy Nizni peat bog $\left(49^{\circ} 17^{\prime} \mathrm{N}, 20^{\circ} 02^{\prime} \mathrm{E}\right)$, water from beneath the surface. SEM description: This stomatocyst is small, smooth and spherical, 4.7-4.9 $\mu \mathrm{m}$ in diameter. The collar is slightly conical, $1.2-1.3 \mu \mathrm{m}$ in diameter and $0.5 \mu \mathrm{m}$ in height, with a reflexed back towards the cyst body apex. This stomatocyst is distinguished from stomatocyst 273 Gilbert \& Smol on the basis of collar morphology. References: We have not definitively identified this stomatocyst elsewhere.

With a simple obconical collar

*Stomatocyst 182, Brown \& Smol in Brown et al. 1994 (Fig. 18). Negative number: 4N-10. Number of specimens: 2. Biological affinity: Unknown. Locality: Staw Toporowy Nizni peat bog (49 $\left.17^{\prime} \mathrm{N}, 20^{\circ} 02^{\prime} \mathrm{E}\right)$, water squeezed from Sphagnum spp. SEM description: This stomatocyst is smooth and spherical, 5.9-8.7 $\mu \mathrm{m}$ in diameter. The collar is obconical, $2.2-2.7 \mu \mathrm{m}$ in diameter and $0.2-0.3 \mu \mathrm{m}$ in height, with a very wide, flattened, and obconical apex. The regular pore, 0.2-0.3 $\mu \mathrm{m}$ in diameter, is surrounded by a swollen annulus. This stomatocyst is distinguished from stomatocyst 125 Duff \& Smol on the basis of size of collar. Stoma- 

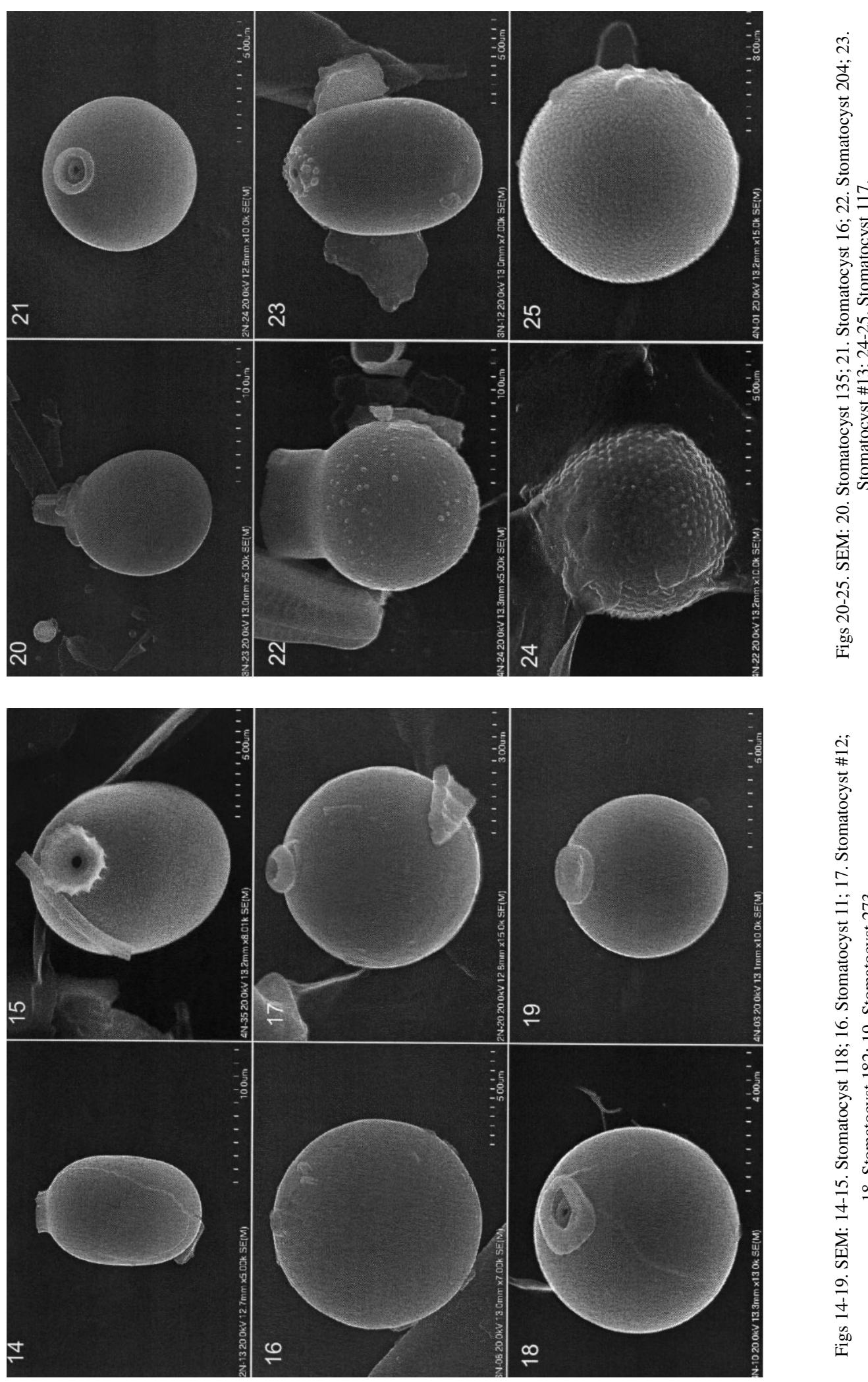

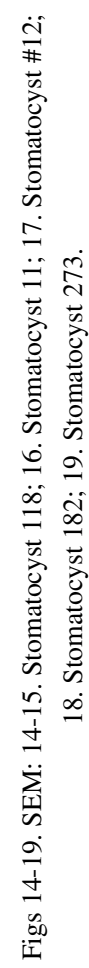


tocyst 182 has two times larger of collar. Notes: The diameter of our stomatocyst is larger than in original description $(5.2-6.7 \mu \mathrm{m})$. References: This stomatocyst has been found in Greenland (Duff et al. 1995) and the Spanish part of Pyrenees (Pla 2001).

With a true or false complex collar

**Stomatocyst 273, Gilbert \& Smol in Gilbert et al. 1997 (Fig. 19). Negative number: 4N-03. Number of specimens: 2. Biological affinity: Unknown. Locality: Staw Toporowy Nizni peat bog $\left(49^{\circ} 17^{\prime} \mathrm{N}, 2^{\circ} 02^{\prime} \mathrm{E}\right)$, water squeezed from Sphagnum spp. SEM description: This stomatocyst is smooth and spherical, 5.8-6.1 $\mu \mathrm{m}$ in diameter, with a false complex collar, 1.8-2.2 $\mu \mathrm{m}$ in diameter and $0.3-0.4 \mu \mathrm{m}$ in height. This stomatocyst is distinguished from stomatocyst 182 Brown \& Smol on the basis of body size, and morphology and size of collar. References: This stomatocyst has been found in Russia - Siberia (Wilkinson et al. 2001).

Stomatocyst 135, Duff \& Smol 1991 (in Pla 2001) (Figs 20, 51-52). Negative number: 3N-23. Number of specimens: 3. Biological affinity: Unknown, but several species of Uroglena are known to produce cysts with hooked collar projections (Duff et al. 1995). Locality: Staw Toporowy Nizni peat bog $\left(49^{\circ} 17^{\prime} \mathrm{N}\right.$, $20^{\circ} 02^{\prime} \mathrm{E}$ ), sediment from the bottom of the peat bog. SEM description: This stomatocyst is smooth and oval, 10.2-11.5 $\mu \mathrm{m}$ long, 9.0-9.5 $\mu \mathrm{m}$ wide. It has characteristic complex collar; the wide, obconical tertiary collar, $4.9 \mu \mathrm{m}$ in diameter, is separated from the secondary collar by a planar interannulus. Our specimens are very similar to stomatocyst 135 Duff \& Smol reported by Pla (2001: Fig. E3). This stomatocyst is distinguished from stomatocyst 67 Hansen (Hansen 2001) on the basis of ornamentation. References: This stomatocyst has been found in Canada, U.S.A., Denmark, Spain, Argentina, Kerguelen Islands (Duff et al. 1995), and the Spanish part of Pyrenees (Pla 2001). Stomatocyst 135 has been previously described from Poland by Cabala (2002) as unidentified stomatocyst $=$ Type 160 Adam. The description is emended at this time.

*Stomatocyst 16, Duff \& Smol in Duff et al. 1995 (Fig. 21). Negative number: 2N-24. Number of specimens: 3. Biological affinity: Unknown. Locality: Staw Toporowy Nizni peat bog $\left(49^{\circ} 17^{\prime} \mathrm{N}, 20^{\circ} 02^{\prime} \mathrm{E}\right)$, water from beneath the surface. SEM description: This stomatocyst is smooth and spherical, 5.6-5.8 $\mu \mathrm{m}$ in dia- meter. The primary collar is low, cylindrical to slightly conical, $0.7 \mu \mathrm{m}$ in diameter, and surrounds the regular pore, $0.3 \mu \mathrm{m}$ in diameter. The secondary collar is cylindrical, $1.8 \mu \mathrm{m}$ in diameter. This stomatocyst is distinguished from stomatocyst 127 Duff \& Smol on the basis of collar morphology. Notes: The diameter of our stomatocyst is smaller than in original description $(7.5-11.2 \mu \mathrm{m})$, the diameter of primary and secondary collars and pore are smaller, too. References: This stomatocyst has been found in Canada, U.S.A. (Duff et al. 1995), central Europe (Facher \& Schmidt 1996) and the Spanish part of Pyrenees (Pla 2001).

*Stomatocyst 204, Duff \& Smol 1994 (Figs 22, 53$55)$. Negative number: $4 \mathrm{~N}-24$. Number of specimens: 7. Biological affinity: This stomatocyst is produced by Uroglena volvox Ehrenberg (Duff et al. 1995). Locality: Staw Toporowy Nizni peat bog $\left(49^{\circ} 17^{\prime} \mathrm{N}\right.$, $\left.20^{\circ} 02^{\prime} \mathrm{E}\right)$, water squeezed from Sphagnum spp. SEM description: This stomatocyst is smooth or ornamented with irregular verrucae. It is spherical, 9.1-12.9 $\mu \mathrm{m}$ in diameter, with a true complex collar; the secondary collar is cylindrical, 7.4-8.2 $\mu \mathrm{m}$ in diameter and 2.7$4.8 \mu \mathrm{m}$ in height. References: This stomatocyst has been found in Canada, U.S.A., Sweden, France (Duff et al. 1995) and the Spanish part of Pyrenees (Pla 2001).

Ornamented stomatocysts (Duff et al. 1995, Wilkinson et al. 2001)

With anterior projections simulating simple/complex collar

***Stomatocyst \#13, Cabala J., this paper. (Fig. 23). Negative number: J. Cabala, negative 3N-12, Fig. 23. Number of specimens: 1. Biological affinity: Unknown. Locality: Staw Toporowy Nizni peat bog $\left(49^{\circ} 17^{\prime} \mathrm{N}, 20^{\circ} 02^{\prime} \mathrm{E}\right)$, sediment from the bottom of the peat bog. SEM description: This stomatocyst is smooth and oval, $10.3 \mu \mathrm{m}$ long, $7.2 \mu \mathrm{m}$ wide. The pore is regular, $0.5 \mu \mathrm{m}$ in diameter. The collar is conical, $0.8 \mu \mathrm{m}$ in diameter and $0.3 \mu \mathrm{m}$ in height, approximately the collar the siliceous projections are located; they form a ring which surrounds the collar. This stomatocyst is distinguished from stomatocyst 277 Gilbert \& Smol on the basis of collar and pore morphology. References: We have not definitively identified this stomatocyst elsewhere.

With scabrae

**Stomatocyst 117, Zeeb et al. $1990($ Figs 24-25) = 
Stomatocyst 58, Hansen 2001, syn. nov. Negative number: 4N-22. Number of specimens: 4. Biological affinity: Unknown. Locality: Staw Toporowy Nizni peat bog $\left(49^{\circ} 17^{\prime} \mathrm{N}, 20^{\circ} 02^{\prime} \mathrm{E}\right)$, water from beneath the surface, sediment from the bottom of the peat bog and water squeezed from Sphagnum spp. SEM description: This stomatocyst is spherical, 5.0-6.8 $\mu \mathrm{m}$ in diameter. The collar is low and cylindrical to obconical, 1.4-1.5 $\mu \mathrm{m}$ in diameter. The pore is conical, $0.3 \mu \mathrm{m}$ in diameter. The entire cyst surface is with a rounded scabrae arranged equidistantly in a regular pattern (scabrae diameter $0.2-0.3 \mu \mathrm{m}$, height $0.2 \mu \mathrm{m}$ ). This stomatocyst is distinguished from stomatocyst 210 Duff \& Smol on the basis of ornamentation. Stomatocyst 117 is very similar to stomatocyst 58 Hansen (Hansen 2001) and the two may represent the same morphotype. References: This stomatocyst has been found in Canada, U.S.A. (Duff et al. 1995) and Azores (Hansen 2001).

Stomatocyst 178, Zeeb \& Smol 1993 (Fig. 26). Negative number: $2 \mathrm{~N}-10$. Number of specimens: 6 . Biological affinity: Unknown. Locality: Staw Toporowy Nizni peat bog $\left(49^{\circ} 17^{\prime} \mathrm{N}, 20^{\circ} 02^{\prime} \mathrm{E}\right)$, water from surface, water from beneath the surface, and water squeezed from Sphagnum spp. SEM description: This stomatocyst is spherical, 5.1-5.6 $\mu \mathrm{m}$ in diameter. The collar is cylindrical to obconical, 1.6-1.8 $\mu \mathrm{m}$ in diameter and $0.2-0.4 \mu \mathrm{m}$ in height. The pore is conical, $0.3 \mu \mathrm{m}$ in diameter. The cyst surface is covered with a regular reticulum, consisting of rounded scabrae arranged in groups of six to form hexagonal lacunae. This stomatocyst is distinguished from stomatocysts 117 Zeeb et al. and 210 Duff \& Smol on the basis of ornamentation. References: This stomatocyst has been found in Canada, U.S.A., Sweden, Poland (Duff et al. 1995), Irkutsk Reservoir, Siberia (Vorobyova et al. 1996), central Europe (Facher \& Schmidt 1996) and the Spanish part of Pyrenees (Pla 2001).

* Stomatocyst 188 Brown \& Smol in Brown et al. 1994 (Figs 27 \& 56). Negative number: 2N-18. Number of specimens: 2. Biological affinity: Unknown. Locality: Staw Toporowy Nizni peat bog $\left(49^{\circ} 17^{\prime} \mathrm{N}\right.$, $\left.20^{\circ} 02^{\prime} \mathrm{E}\right)$, water from beneath the surface. SEM description: This stomatocyst is spherical, $8.5-8.8 \mu \mathrm{m}$ in diameter. The collar is cylindrical, $1.2-1.4 \mu \mathrm{m}$ in diameter and $0.5 \mu \mathrm{m}$ in height. The pore is regular, 0.4-0.5 $\mu \mathrm{m}$ in diameter. The stomatocyst surface is smooth to slightly ornamented, with scabrae, $0.2-0.3 \mu \mathrm{m}$ in diameter, which are located mainly on the anterior hemisphere. This stomatocyst is distinguished from stomato- cysts 206 Duff \& Smol and 11 Facher \& Schmidt on the basis of ornamentation and collar morphology; from stomatocyst 10 Facher \& Schmidt on the basis of ornamentation. Notes: The diameters of the collar and the pore of our stomatocyst are smaller than in original description (1.5-2.4 $\mu \mathrm{m}$ and 0.6-0.9 $\mu \mathrm{m}$, respectively). References: This stomatocyst has been found in Greenland, Canada, (Duff et al. 1995) and the Spanish part of Pyrenees (Pla 2001).

***Stomatocyst \#14, Cabala J., this paper (Figs 28$29 \& 57)$. Negative number: J. Cabala, negative $2 \mathrm{~N}$ 29, Fig. 28. Number of specimens: 4. Biological affinity: Unknown. Locality: Staw Toporowy Nizni peat bog $\left(49^{\circ} 17^{\prime} \mathrm{N}, 20^{\circ} 02^{\prime} \mathrm{E}\right)$, water from beneath the surface and water squeezed from Sphagnum spp. SEM description: This stomatocyst is spherical, 6.6-7.1 $\mu \mathrm{m}$ in diameter. The conical pore is small, $0.2 \mu \mathrm{m}$ in diameter, surrounded by a false complex collar. The outer collar margin is slightly obconical, 1.4-1.6 $\mu \mathrm{m}$ in diameter and $0.2 \mu \mathrm{m}$ in height. The inner collar margin is cylindrical to obconical, $0.9 \mu \mathrm{m}$ in diameter and 0.2 $0.3 \mu \mathrm{m}$ in height. The secondary collar is separated from the primary collar by a planar interannulus. The entire cyst surface is covered with a scabrae, 0.2-0.3 $\mu \mathrm{m}$ in diameter arranged equidistantly in regular pattern with a distance of $0.2-0.3 \mu \mathrm{m}$ between scabrae. This stomatocyst is distinguished from stomatocysts 117 Zeeb et al., 210, 73 Duff \& Smol and 317 Brown et al. on the basis of collar morphology and ornamentation; from stomatocyst 10 van de Vijver \& Beyens on the basis of collar morphology. References: We have not definitively identified this stomatocyst elsewhere.

\section{With verrucae}

***Stomatocyst \#15, Cabala J., this paper (Figs 3031). Negative number: J. Cabala, negative 2N-44, Fig. 30. Number of specimens: 3. Biological affinity: Unknown. Locality: Staw Toporowy Nizni peat bog $\left(49^{\circ} 17^{\prime} \mathrm{N}, 20^{\circ} 02^{\prime} \mathrm{E}\right)$, water from beneath the surface. SEM description: This stomatocyst is oval, 15.3-16.2 $\mu \mathrm{m}$ long, 13.3-13.6 $\mu \mathrm{m}$ wide. The collar is conical, $1.4-1.6 \mu \mathrm{m}$ in diameter and $0.5 \mu \mathrm{m}$ in height. The pore is regular, $0.9 \mu \mathrm{m}$ in diameter. The stomatocyst surface is ornamented with low verrucae, $0.4-0.7 \mu \mathrm{m}$ in diameter. This stomatocyst is distinguished from stomatocyst 356 Taylor \& Smol on the basis of ornamentation and size. References: We have not definitively identified this stomatocyst elsewhere. 


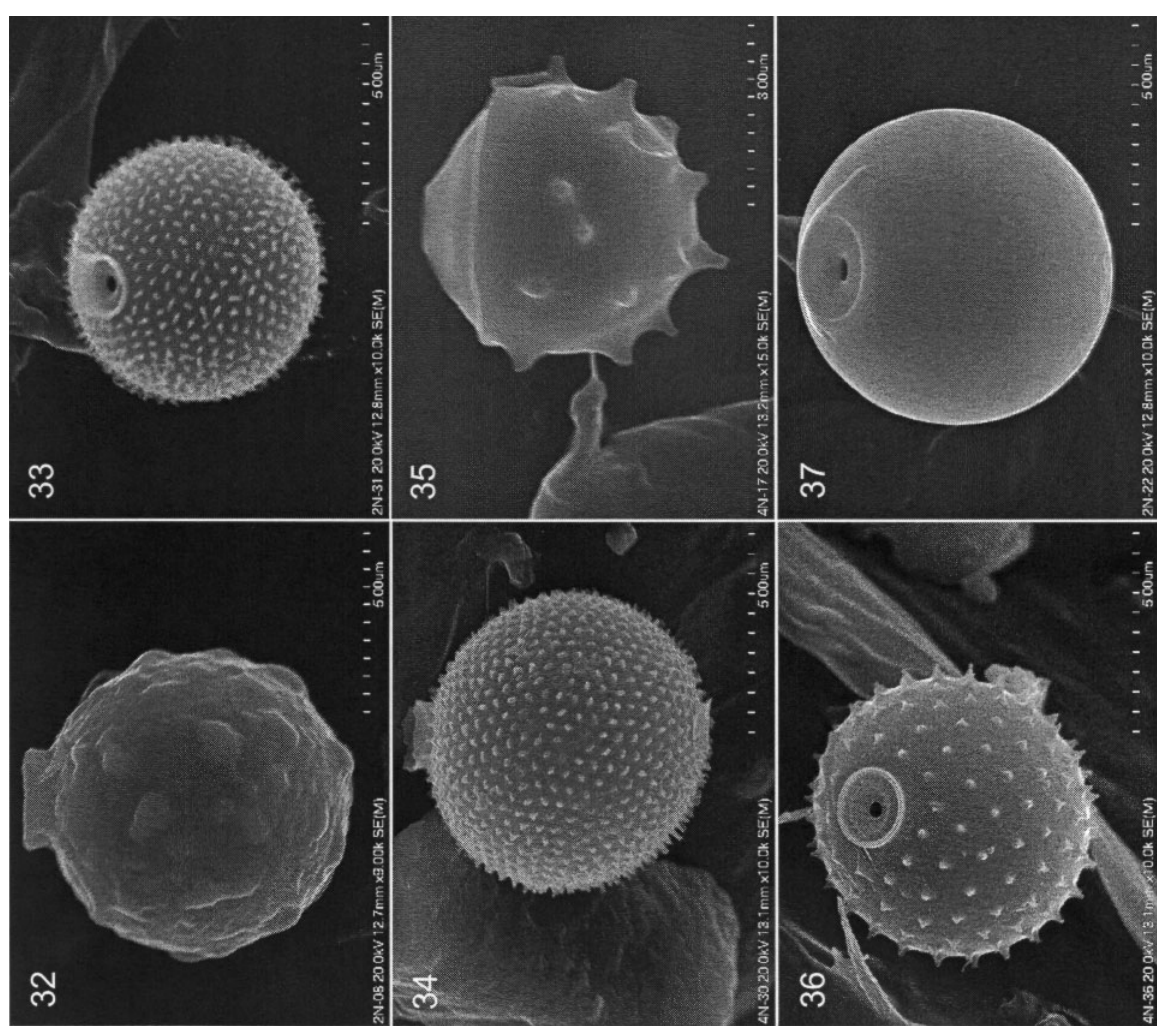

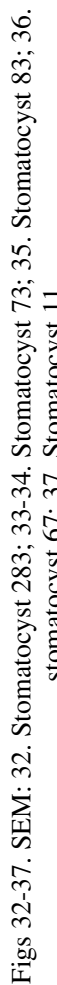

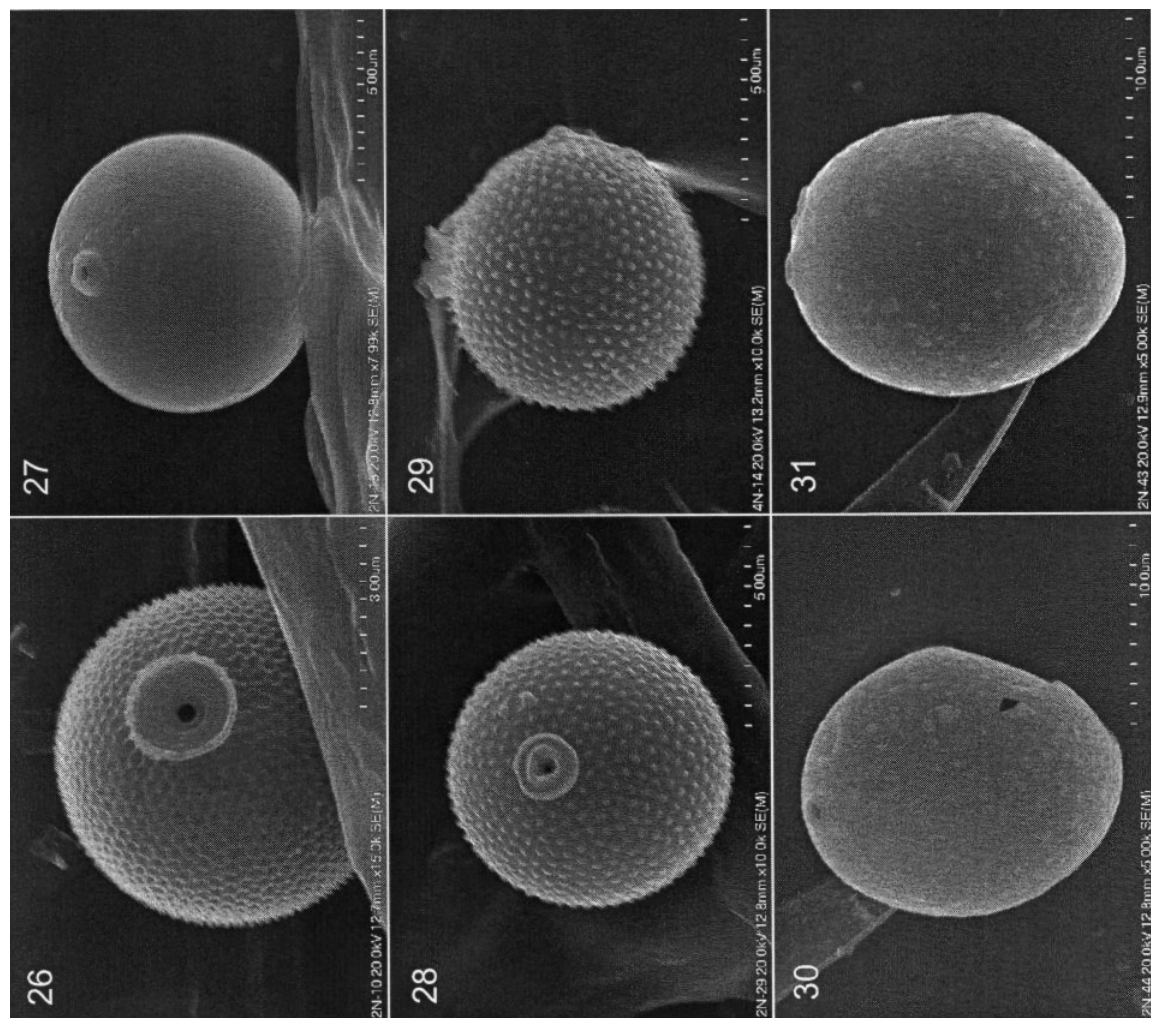

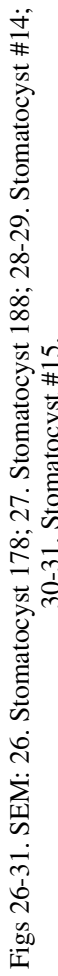




\begin{abstract}
With conula
**Stomatocyst 283, Gilbert \& Smol in Gilbert et al. 1997 (Fig. 32). Negative number: 2N-08. Number of specimens: 3. Biological affinity: Unknown. Locality: Staw Toporowy Nizni peat bog $\left(49^{\circ} 17^{\prime} \mathrm{N}, 20^{\circ} 02^{\prime} \mathrm{E}\right)$, water from surface and water from beneath the surface. SEM description: This stomatocyst is spherical, 7.4$8.3 \mu \mathrm{m}$ in diameter. The collar is cylindrical, $2.5 \mu \mathrm{m}$ in diameter and $0.8 \mu \mathrm{m}$ in height. The pore is not visible. The entire cyst surface is covered with a conula and verrucae. References: This stomatocyst has been found in Russia - Siberia and the Kerguelen Archipelago (Wilkinson et al. 2001).
\end{abstract}

\section{With spines}

*Stomatocyst 73, Duff \& Smol 1991 (Figs 33-34). Negative number: 2N-31. Number of specimens: 11 . Biological affinity: Unknown. Locality: Staw Toporowy Nizni peat bog $\left(49^{\circ} 17^{\prime} \mathrm{N}, 20^{\circ} 02^{\prime} \mathrm{E}\right)$, water from beneath the surface and water squeezed from Sphagnum spp. SEM description: This stomatocyst is spherical, 6.4-6.9 $\mu \mathrm{m}$ in diameter. The secondary collar is obconical, with an irregular apex, 1.5-2.5 $\mu \mathrm{m}$ in diameter and $0.4-0.5 \mu \mathrm{m}$ in height. The conical pore, 0.4 $\mu \mathrm{m}$ in diameter, is surrounded by a small conical primary collar with an acute apex. The entire cyst surface is ornamented with spines arranged equidistantly in a regular pattern (spines with $0.1-0.2 \mu \mathrm{m}$ in diameter and $0.2-0.3 \mu \mathrm{m}$ in height). This stomatocyst is distinguished from 117 Zeeb et al. on the basis of morphology and ornamentation of collar; from stomatocyst 70 van de Vijver \& Beyens on the basis of size; from stomatocyst \#14 Cabala on the basis of morphology and size of collar, and ornamentation of cyst body. References: This stomatocyst has been found in Canada, U.S.A. (Duff et al. 1995), central Europe (Facher \& Schmidt 1996) and the Spanish part of Pyrenees (Pla 2001).

**Stomatocyst 83, Duff \& Smol 1991 (Fig. 35). Negative number: $4 \mathrm{~N}-17$. Number of specimens: 1. Biological affinity: Unknown. Locality: Staw Toporowy Nizni peat bog $\left(49^{\circ} 17^{\prime} \mathrm{N}, 20^{\circ} 02^{\prime} \mathrm{E}\right)$, water squeezed from Sphagnum spp. SEM description: This stomatocyst is spherical, $4.5 \mu \mathrm{m}$ in diameter. The primary collar is conical, $1.1 \mu \mathrm{m}$ in diameter and $0.2 \mu \mathrm{m}$ in height. The primary collar is separated from the secondary collar by a smooth planar interannulus. The secondary collar is low, $4.3 \mu \mathrm{m}$ in diameter and $0.1 \mu \mathrm{m}$ in height. The surface below the secondary collar is ornamented with echinate spines, $0.5 \mu \mathrm{m}$ long and $0.2-0.3 \mu \mathrm{m}$ wi- de. This stomatocyst is distinguished from stomatocysts 84 and 217 Duff \& Smol on the basis of collar morphology. References: This stomatocyst has been found in Canada and U.S.A. (Duff et al. 1995).

**Stomatocyst 67, van de Vijver B. \& Beyens L. 2000 (Fig. 36). Negative number: 4N-36. Number of specimens: 1. Biological affinity: Unknown. Locality: Staw Toporowy Nizni peat bog (49 $17^{\prime}$ N , $\left.20^{\circ} 02^{\prime} \mathrm{E}\right)$, water squeezed from Sphagnum spp. SEM description: This stomatocyst is spherical, $6.4 \mu \mathrm{m}$ in diameter. The primary collar is $1.4-1.6 \mu \mathrm{m}$ in diameter, the secondary collar is slightly obconical, $2.5 \mu \mathrm{m}$ in diameter and $0.3 \mu \mathrm{m}$ in height. The pore is conical, $0.4 \mu \mathrm{m}$ in diameter, with a swollen pseudoannulus. The surface is ornamented with echinate spines, $0.3 \mu \mathrm{m}$ long and 0.2 $0.3 \mu \mathrm{m}$ wide. Notes: The diameter of our stomatocyst is larger than in original description $(5.8 \mu \mathrm{m})$, the diameter of primary and secondary collars are larger, too. This stomatocyst is distinguished from stomatocyst 312 Brown \& Smol on the basis of size, collar morphology and ornamentation; from stomatocyst 73 Hansen (2001) on the basis of size; from stomatocyst 51 Facher E. \& Schmidt R. on the basis of collar and pore morphology. References: This stomatocyst has been found in South Georgia, Antarctica (van de Vijver \& Beyens 2000).

\section{With ridges}

**Stomatocyst 11, Duff \& Smol 1988 emend. Gilbert \& Smol in Gilbert et al. 1997 (Fig. 37). Negative number: 2N-22. Number of specimens: 1. Biological affinity: Unknown. Locality: Staw Toporowy Nizni peat bog $\left(49^{\circ} 17^{\prime} \mathrm{N}, 20^{\circ} 02^{\prime} \mathrm{E}\right)$, water from beneath the surface. SEM description: This stomatocyst is smooth and spherical, $7.8 \mu \mathrm{m}$ in diameter. The pore is regular, $0.5 \mu \mathrm{m}$ in diameter. The collar is wide, slightly conical, $2.5 \mu \mathrm{m}$ in diameter and $0.3 \mu \mathrm{m}$ in height. The outer margin of the collar is continuous with the stomatocyst body. There is one thin ridge extending from the collar edge longitudinally towards the equator. This stomatocyst is distinguished from stomatocysts 42 and 120 Duff \& Smol on the basis of presence of the single ridge. References: This stomatocyst has been found in Canada and Russia - Siberia (Wilkinson et al. 2001).

*Stomatocyst 239, Duff et al. 1995 (Fig. 38) = Stomatocyst 91, Hansen 2001, syn. nov. Negative number: 2N-37. Number of specimens: 2. Biological affinity: Unknown. Locality: Staw Toporowy Nizni peat bog $\left(49^{\circ} 17^{\prime} \mathrm{N}, 20^{\circ} 02^{\prime} \mathrm{E}\right)$, water from beneath the surfa- 

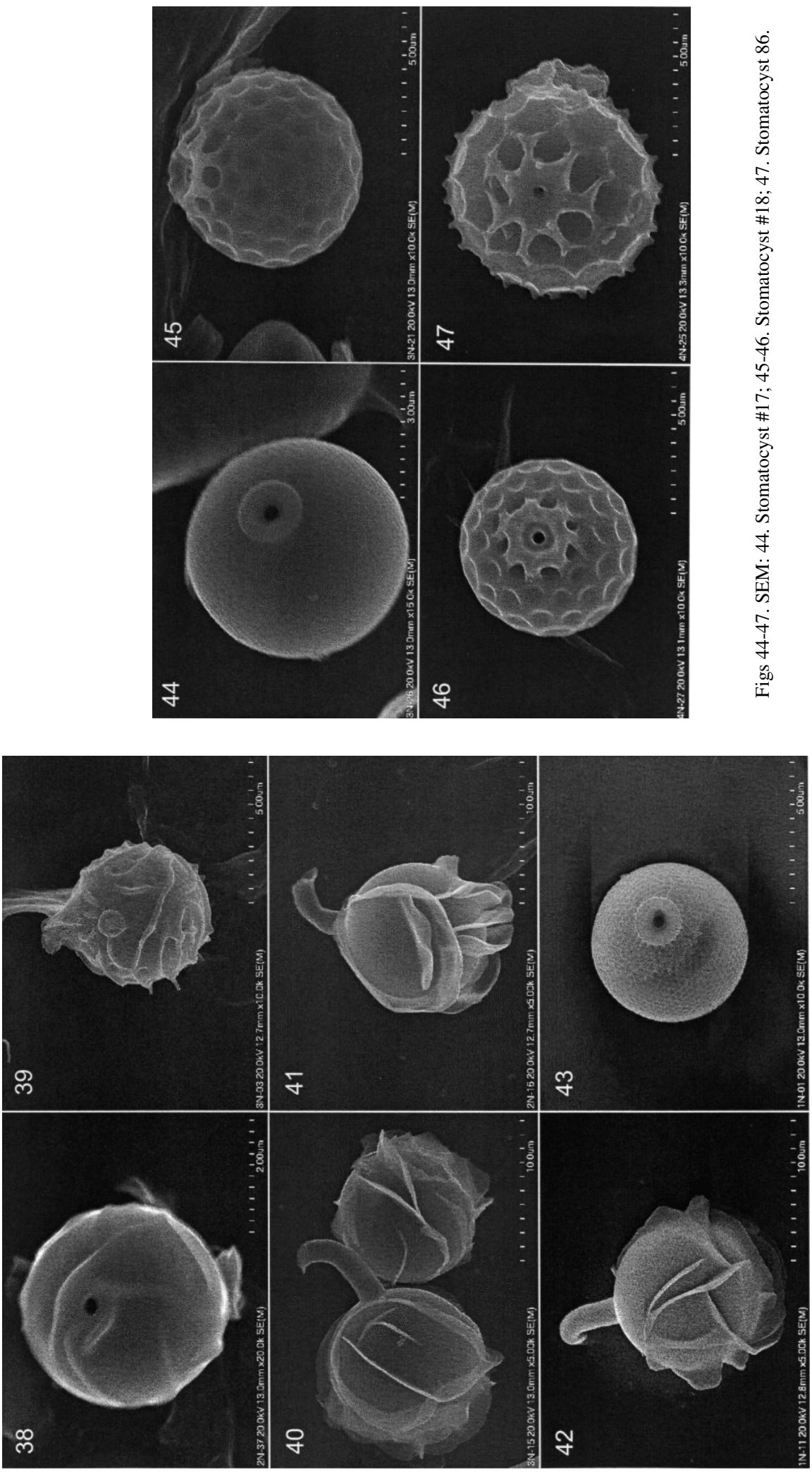

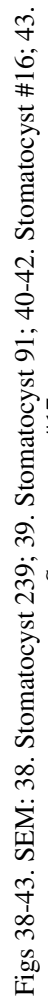



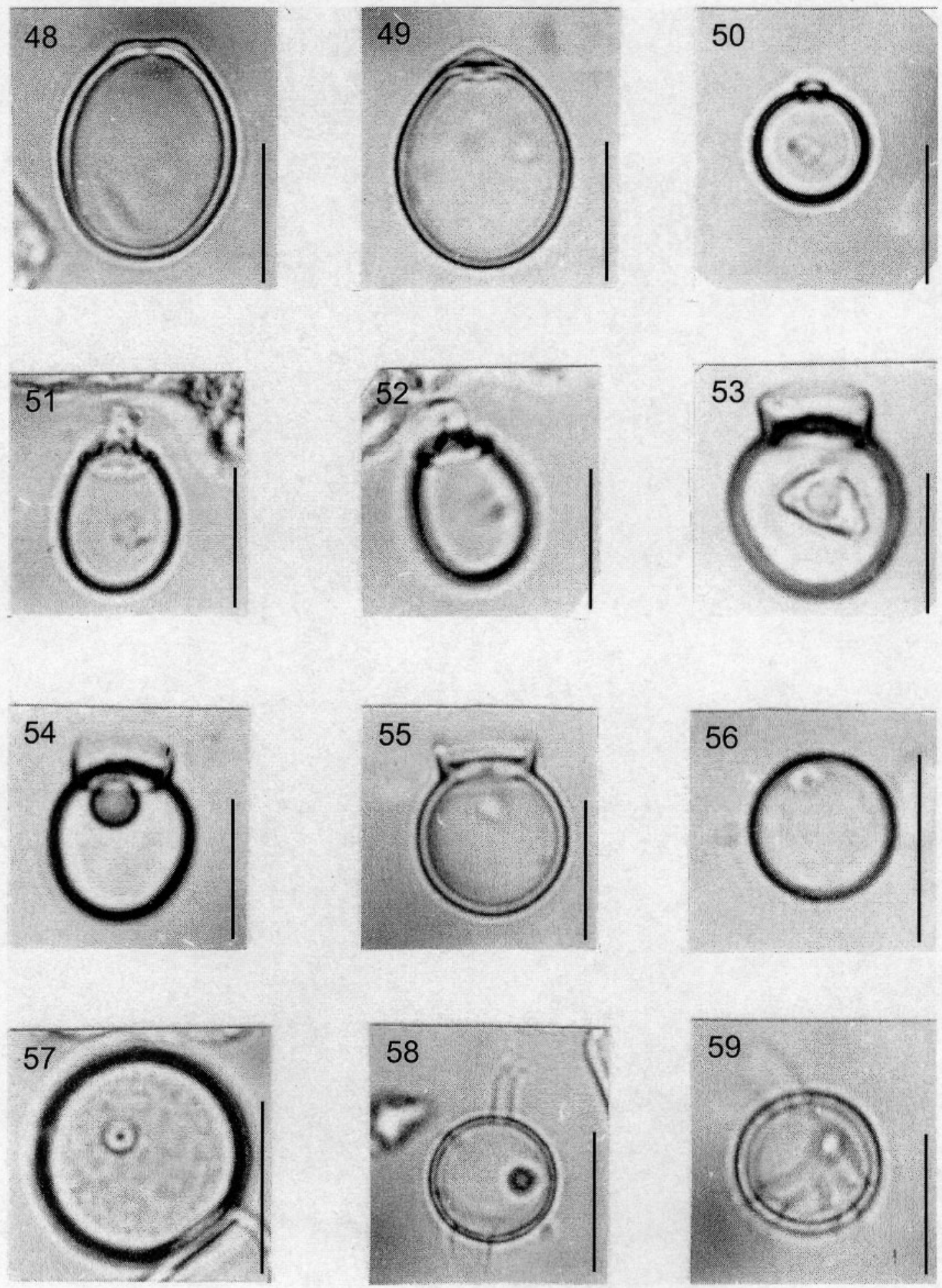

Figs 48-59. LM: 48-49. Stomatocyst 351; 50. Stomatocyst \#12; 51-52. Stomatocyst 135; 53-55. Stomatocyst 204; 56. Stomatocyst $188 ; 57$. Stomatocyst \#14; 58-59. Stomatocyst \#16. Scale bars $=5 \mu \mathrm{m}$ (50 \& 57); scale bars $=10 \mu \mathrm{m}(48-49,51-56,58-59)$. 
ce. SEM description: This stomatocyst is small and spherical, 3.5-3.7 $\mu \mathrm{m}$ in diameter. The pore is regular, $0.3-0.4 \mu \mathrm{m}$ in diameter. The collar is not true, but two or more ridges are usually located near the pore and may fuse to form an incomplete or false collar. This stomatocyst is distinguished from stomatocyst 94 Duff $\&$ Smol on the basis of ornamentation; from stomatocyst 91 Duff \& Smol on the basis of collar. Stomatocyst 239 Duff et al. is inseparable morphologically from stomatocyst 91 Hansen (Hansen 2001), and in the authors' opinion both of these may represent the same morphotype. References: This stomatocyst has been found in Canada, U.S.A. (Duff et al. 1995), Azores (Hansen 2001) and the Spanish part of Pyrenees (Pla 2001).

*Stomatocyst 91, Duff \& Smol 1991 (Fig. 39). Negative number: $3 \mathrm{~N}-03$. Number of specimens: 1 . Biological affinity: Unknown. Locality: Staw Toporowy Nizni peat bog $\left(49^{\circ} 17^{\prime} \mathrm{N}, 20^{\circ} 02^{\prime} \mathrm{E}\right)$, sediment from the bottom of the peat bog. SEM description: This stomatocyst is small and spherical, $4.8 \mu \mathrm{m}$ in diameter. The collar is obconical, $0.9 \mu \mathrm{m}$ in diameter and $0.7 \mu \mathrm{m}$ in height, with a thickened apex. The cyst surface is covered with low ridges, $0.2 \mu \mathrm{m}$ in height. This stomatocyst is distinguished from stomatocyst 92 Duff \& Smol on the basis of ornamentation and collar morphology; from stomatocysts 33 and 222 Duff \& Smol on the basis of ornamentation (ridge length); from stomatocyst 113 Zeeb et al. on the basis of ridge morphology. References: This stomatocyst has been found in Canada, U.S.A. (Duff et al. 1995) and the Spanish part of Pyrenees (Pla 2001).

***Stomatocyst \#16, Cabala J., this paper (Figs 4042, 58-59). Negative number: J. Cabala, negative $3 \mathrm{~N}-$ 15, Fig. 40. Number of specimens: 25. Biological affinity: Unknown. Locality: Staw Toporowy Nizni peat bog $\left(49^{\circ} 17^{\prime} \mathrm{N}, 20^{\circ} 02^{\prime} \mathrm{E}\right)$, water from surface, water from beneath the surface, sediment from the bottom of the peat bog, and water squeezed from Sphagnum spp. SEM description: This stomatocyst is spherical, 8.4$10.7 \mu \mathrm{m}$ in diameter. The collar is long, cylindrical and crooked, 1.6-2.4 $\mu \mathrm{m}$ in diameter and 5.1-7.3 $\mu \mathrm{m}$ in height. The details of the inner collar and the pore morphology are unknown. The cyst surface is covered with long ridges, 0.7-3.4 $\mu \mathrm{m}$ in height, usually starting at some distance from the collar base, but extending to the posterior pole. Stomatocyst \#16 Cabala J. resembles stomatocyst 173 Zeeb \& Smol (Duff et al. 1995, Facher \& Schmidt 1996) from which it can be distinguished by the following features: stomatocysts 173 is two times larger and it lacks the characteristic crooked collar. It resembles also stomatocysts 238 Duff et al. (Duff et al. 1995, Pla 2001) and 367 Pla (2001), but differs from these morphotypes by its ornamentation and collar morphology. Furthermore, stomatocyst \#16 Cabala J. is similar to stomatocyst 41 Duff \& Smol, from which it is distinguished on the basis of ornamentation. References: We have not definitively identified this stomatocyst elsewhere.

\section{With a reticulum}

***Stomatocyst \#17, Cabala J., this paper (Figs 4344). Negative number: J. Cabala, negative 1N-01, Fig. 43. Number of specimens: 4. Biological affinity: Unknown. Locality: Staw Toporowy Nizni peat bog $\left(49^{\circ} 17^{\prime} \mathrm{N}, 20^{\circ} 02^{\prime} \mathrm{E}\right)$, water from surface, water from beneath the surface and sediment from the bottom of the peat bog. SEM description: This stomatocyst is spherical, $5.2-5.5 \mu \mathrm{m}$ in diameter. The pore is regular, 0.3-0.4 $\mu \mathrm{m}$ in diameter, with a planar pseudoannulus. The collar is cylindrical to slightly obconical, 1.5-1.6 $\mu \mathrm{m}$ in diameter and $0.2-0.4 \mu \mathrm{m}$ in height. The cyst surface is covered by regular reticulum with small lacunae, which have polygonal shape (lacunae with diameter of $0.2 \mu \mathrm{m}$; the distance between lacunae is ca 0.1 $\mu \mathrm{m})$. This stomatocyst is distinguished from stomatocyst 178 Zeeb \& Smol on the basis of collar morphology and ornamentation of cyst body. References: We have not definitively identified this stomatocyst elsewhere.

***Stomatocyst \#18, Cabala J., this paper (Figs 4546). Negative number: J. Cabala, negative 4N-27, Fig. 46. Number of specimens: 8. Biological affinity: Unknown. Locality: Staw Toporowy Nizni peat bog $\left(49^{\circ} 17^{\prime} \mathrm{N}, 20^{\circ} 02^{\prime} \mathrm{E}\right)$, sediment from the bottom of the peat bog and water squeezed from Sphagnum spp. SEM description: This stomatocyst is spherical, 6.1$7.0 \mu \mathrm{m}$ in diameter. The pore is regular, $0.4 \mu \mathrm{m}$ in diameter, with a planar pseudoannulus. The collar is conical, polygonal in outline, with a basal diameter of 2.9$3.2 \mu \mathrm{m}$, apical diameter of 1.8-2.0 $\mu \mathrm{m}$, and height of $0.6-0.8 \mu \mathrm{m}$. The cyst surface is covered by regular reticulum with circular lacunae (lacunae with diameter of 0.5-0.8 $\mu \mathrm{m}$; the distance between lacunae is ca 0.2$0.3 \mu \mathrm{m})$. This stomatocyst is distinguished from stomatocyst 231 Duff \& Smol on the basis of collar morphology and ornamentation; from stomatocyst 255 Wilkinson \& Smol on the basis of shape, collar morphology and ornamentation; and from stomatocyst 305 
Pla on the basis of collar morphology. References: We have not definitively identified this stomatocyst elsewhere.

\section{With compound ornamentation}

*Stomatocyst 86, Duff \& Smol 1991 (Fig. 47). Negative number: 4N-25. Number of specimens: 16 . Biological affinity: Unknown. Locality: Staw Toporowy Nizni peat bog $\left(49^{\circ} 17^{\prime} \mathrm{N}, 20^{\circ} 02^{\prime} \mathrm{E}\right)$, water from beneath the surface, sediment from the bottom of the peat bog, and water squeezed from Sphagnum spp. SEM description: This stomatocyst is spherical, 6.4-7.4 $\mu \mathrm{m}$ in diameter with unusual collar. The pore is regular, $0.3-0.4 \mu \mathrm{m}$ in diameter with a slight conical primary collar. The secondary collar is cylindrical and polygonal in outline. From each corner a straight ridge radiates. The cyst surface is covered with a low variable, polygonal reticulum with echinate spines, $0.3-0.5 \mu \mathrm{m}$ in height, which are located at each reticular interstice. References: This stomatocyst has been found in Canada, U.S.A. (Duff et al. 1995), central Europe (Facher \& Schmidt 1996) and the Spanish part of Pyrenees (Pla 2001).

\section{Discussion}

The Staw Toporowy Nizni peat bog is a cold and mountain-type peat bog. This characterization is supported by the occurrence of stomatocysts previously observed in cold waters: 181 Brown \& Smol, 118 Zeeb et al., 273 Gilbert \& Smol, 135 Duff \& Smol, 16 Duff \& Smol, 283 Gilbert \& Smol, 83 Duff \& Smol, 11 Duff $\&$ Smol and 91 Duff \& Smol. These stomatocysts were found by other authors in arctic and alpine habitats such as arctic tundra lakes, arctic peats, arctic ponds, alpine ponds and montane lakes, and this suggests that they are produced by a cold-tolerant form. They may be considered as indicators of cold mountain habitats. The chemical and physical parameters of the water suggested a dystrophic status (Table 1), as reported earlier by Bembówna (1969). Interestingly, two stomatocysts (181 and 83) are strongly associated with poor waters.

The ornamentation-dependent vertical distribution of some stomatocysts is particularly interesting. Unornamented stomatocysts dominated in the bottom sediments, whereas ornamented stomatocysts were rare in this part of peat bog (Table 2). Unornamented stomatocysts were also rather abundant in water squeezed from Sphagnum spp. and water from beneath the surface, and were completely absent from the surface wa- ter. Some ornamented stomatocysts have «airfoils» with various types of ridges, conula, scabrae, etc. (e.g., Figs 24-29, 32, 37-42) which facilitate free floating in the water. This functional explanation is supported by the presence of ornamented forms at the surface and beneath the surface of the water. Such a phenomenon has been reported by Adam and Mahood (1981). These authors also suggested that the spines may play a role in keeping cysts attached to their substrates. This assumption is partly confirmed in our studies: only three stomatocysts with spines found in Toporowy Staw Nizni peat bog (stomatocysts 73, 83 Duff \& Smol, 67 van de Vijver \& Beyens) were collected in water squeezed from Sphagnum spp.

\section{Acknowledgements}

We thank Professor Konrad Wolowski for his critical remarks and help, two anonymous reviewers for their valuable suggestions, Antoni Pachonski for his help in preparing the LM micrographs, and Anna Latkiewicz for helping in preparing the SEM micrographs, which were taken in the Laboratory of Field Emission Scanning Electron Microscopy and Microanalysis at the Institute of Geological Sciences of the Jagiellonian University. Michael Jacobs has served us as linguistic adviser and we gratefully thank his assistance. This work was supported by the W. Szafer Foundation of Polish Botany.

\section{References}

Adam D.P. \& Mahood A.D. 1981. - Chrysophyte cysts as potential environmental indicators. Geol. Soc. Amer. Bull, Part I, 92, 839844.

Bembówna M. 1969. - Hydrochemical characteristics of the Toporowy Staw Nizni, one the dystrophic Tatra Lakes. Acta Hydrobiol., 11, 223-231.

Brown K.M., Douglas M.S.V. \& Smol J.P. 1994. - Siliceous microfossils in a Holocene, high arctic peat deposit (Nordvesto, northwestern Greenland). Can. J. Bot., 72, 208-216.

Brown K.M., Zeeb B.A., Smol J.P. \& Pienitz R. 1997. - Taxonomic and ecological characterization of chrysophyte stomatocysts from northwestern Canada. Can. J. Bot., 75, 842-863.

Cabala J. 2002. - Chrysophyceae stomatocysts from Budzyn peat bog (Kraków-Czestochowa Upland, Poland). Polish Bot. J., 47, 21-35.

Cabala J. 2003a. - New and rare morphotypes of chrysophycean stomatocysts from Poland. Nova Hedwigia, 77, 99-107.

Cabala J. 2003b. - Three morphotypes of chrysophycean stomatocysts from Poland. Polish Bot. J., 48, 13-16.

Cronberg G. 1980. - Cyst development in different species of Mallomonas (Chrysophyceae) studied by scanning electron microscope. Arch. Hydrobiol. Suppl., 56, 421-434.

Cronberg G. \& Sandgren C.D. 1986. - A proposal for the development of standardised nomenclature and terminology for chrysophycean statospores. Pages 317-328 in Chrysophytes: aspects and problems. Kristiansen J. \& Andersen R.A. (eds.). Cambridge University Press, Cambridge, U.K.

Duff K.E. \& Smol J.P. 1988. - Chrysophycean stomatocyst from the postglacial sediments of a High Arctic lake. Can. J. Bot., 66, 1117-1128. 
Duff K.E. \& Smol J.P. 1991. - Morphological descriptions and stratigraphic distributions of the chrysophycean stomatocysts from a recently acidified lake (Adirondack Park, N.Y.). J. Paleolimnol., 5, 73-113.

Duff K.E. \& Smol J.P. 1994. - Chrysophycean cyst flora from British Columbia (Canada) lakes. Nova Hedwigia, 58, 353-389.

Duff K.E., Douglas M.S.V. \& Smol J.P. 1992. - Chrysophyte cysts in 36 Canadian high arctic ponds. Nord. J. Bot., 12, 471-499.

Duff K.E., Zeeb B.A. \& Smol J.P. 1995. - Atlas of chrysophycean cysts. Developments Hydrobiology 99. Kluwer Academic Publishers, Dordecht.

Facher E. \& Schmidt R. 1996. - A siliceous chrysophycean cyst-based $\mathrm{pH}$ transfer function for Central European lakes. J. Paleolimnol., 16, 275-321.

Gilbert S., Zeeb B.A. \& Smol J.P. 1997. - Chrysophyte stomatocyst flora from a forest peat core in the Lena River Region, northeastern Siberia. Nova Hedwigia, 64, 311-352.

Hansen P. 2001. - Chrysophyte stomatocysts in the Azores - biogeographical implications and 110 new morphotypes. Opera Bot. 138, 1-96.

Kamenik C., Schmidt R., Koinig K.A., Agusti-Panareda A., Thompson R. \& Psenner R. 2001. - The chrysophyte stomatocyst composition in a high alpine lake (Gossenköllesee, Tyrol, Austria) in relation to seasonality, temperature and land-use. Beih. Nova Hedwigia, 122, 1-22.

Lajczak A. 1996. - Hydrology. Tatry i Podtatrze, 3, 169-196.

Mirek Z. \& Piekos-Mirkowa H. 1995. - Szata roslinna Tatr Polskich. Polish Bot. Stud. Guideb. Ser., 12, 73-150.

Peters M.C. \& Andersen R.A. 1993. - The fine structure and scale formation of Chrysolepidomonas dendrolepidota gen. et sp. nov. (Chrysolepidomonadeceae fam. nov., Chrysophyceae). J. Phycol., 29, 469-475.

Pienitz R., Walker I.R., Zeeb B.A., Smol J.P. \& Leavitt P.R. 1992. Biomonitoring past salinity changes in an athalassic subarctic lake. Int. J. Salt Lake Res., 1, 91-123.

Pla S. 2001. - Chrysophycean cysts from the Pyrenees. Biblioth. Phycol., 109, 1-179.
Szeicz J.M., Zeeb B.A., Bennett K.D. \& Smol J.P. 1998. - High-resolution paleoecological analysis of recent disturbance in a southern Chilean Nothofagus forest. J. Paleolimnol., 20, 235-252.

Szklarczyk-Gazdowa C. 1960. - Phytoplankton of some Tatra lakes. Acta Soc. Bot. Poloniae, 29, 597-624.

Takahashi E. 1987. - Loricate and scale-bearing protists from Lützhow-Holm Bay, Antarctica II. Four marine species of Paraphysomonas (Chrysophyceae) including to new species from the fastice covered coastal area. Jap. J. Phycol., 35, 155-166.

Van de Vijver B. \& Beyens L. 1997a. - The subfossil Chrysophyte cyst flora of some peat samples from Kerguelen Islands. Arch. Protistenk., 148, 491-503.

Van de Vijver B. \& Beyens L. 1997b. - The Chrysophyte stomatocyst flora of the moss vegetation from Stromness Bay Area, South Georgia. Arch. Protistenk., 148, 505-520.

Van de Vijver B. \& Beyens L. 2000. - Chrysophycean stomatocysts from freshwater habitats of the Stromness Bay area, South Georgia, Antarctica. Can. J. Bot., 78, 88-97.

Vorobyova S.S., Pomazkina G.V., Baranova E.Yu., Likhoshway Ye.V. \& Sandgren C.D. 1996. - Chrysophycean cysts (stomatocysts) from Lake Baikal and Irkutsk. J. Paleolimnol., 15, 272-277.

Wilkinson A.N. \& Smol J.P. 1998. - Chrysophycean stomatocysts flora from south-central Ontario lakes. Can. J. Bot., 76, 836-862.

Wilkinson A.N., Zeeb B.A. \& Smol J.P. 2001. - Atlas of chrysophycean cysts. Volume II. Developments Hydrobiology 157. Kluwer Academic Publishers, Dordecht

Wolowski K., Cabala J. \& Zeeb B.A. - Chrysophycean stomatocysts from a karstic sink-hole in the vicinity of the Staszow on the Malopolska Upland, Poland. Can. J. Bot., in press.

Zeeb B.A. \& Smol J.P. 1993. - Chrysophycean stomatocyst flora from Elk Lake, Clearwater County, Minnesota. Can. J. Bot., 71, 737-756.

Zeeb B.A., Duff K.E. \& Smol J.P. 1990. - Morphological descriptions and stratigraphic profiles of chrysophycean stomatocysts from the recent sediments of Little Round Lake, Ontario. Nova Hedwigia, 51, 361-380. 